ISSN : 2776-8651 (Online-Elektronik)

\title{
Orchidftgro
}

Vol. 1, No. 1, Bulan Februari Tahun 2021

DOI: http://dx.doi.org/10.35138/orchidagro.v1.i1.231

\section{Pengaruh Konsentrasi Pupuk Organik Cair Dan Takaran Pupuk Kandang Sapi Terhadap Pertumbuhan Dan Hasil Tanaman Selada (Lactuca sativa L.) Varietas Grand Rapids}

\author{
Hanipah, Nurdin Hadirocmat, Odang Hidayat \\ Program Studi Agroteknologi Fakultas Pertanian, Universitas Winaya Mukti \\ Email: hanipahhani@gmail.com
}

(Received: 22-12-20; Published: 20-02-21)

\begin{abstract}
The aim of this experiment was to study the effect of concentration liquid organic fertilizer and doses cow manure on the growth and yield of grand rapids variety of lettuce, carried out in the practice of Tanjungsari Sumedang SMK PPN, located at an altitude of 850 meters above sea level. The experiment starts from June 2018 to August 2018. The experimental design used was a Randomized Design facto pattern group consisting of two factors and repeated three times. The first factor is liquid organic fertilizer nasa $(p)$ with 5 levels: $p 1=0 \mathrm{ml} /$ liter of water, p2 = $1 \mathrm{ml} /$ liter of water, $p 3=2 \mathrm{ml} /$ liter of water, $p 4=3 \mathrm{ml} /$ liter of water, $p 4=4 \mathrm{ml} /$ liter of water. The second factor is cow manure $(k)$ consisting of 4 levels, namely: $k 1=0$ ton $/$ ha, $k 2=5$ ton $/$ ha, $k 3=10$ ton $/$ ha, $k 4=15$ ton $/$ ha. The results of the experiment show: There was no interaction between liquid organic fertilizer and cowshed fertilizer on observations of plant height, number of leaves, weight per plant, weight per sample, weight per plot and root volume in lettuce. The treatment of liquid organic fertilizer at concentrations of p3 (3,0 ml/liter of water) showed the best results on plant height, number of leaves, and yield of weight per plot and significantly different from observations of weight per plant and root volume. Cow manure showed no significant effect on all plant height, number of leaves, weight per plant, weight per sample, weight per plot and root volume in lettuce.
\end{abstract}

Keywords: liquid organic fertilizer, cow manure, lettuce plant.

\begin{abstract}
ABSTRAK
Percobaan ini bertujuan untuk mempelajari pengaruh pupuk oraganik cair nasa dan pupuk kandang sapi terhadap pertumbuhan dan hasil tanaman selada varietas grand rapids, dilaksanakan di kebun praktek SMK PPN Tanjungsari Sumedang yang terletak pada ketinggian 850 meter di atas permukaan laut. Percobaan dimulai dari bulan Juni 2018 sampai Agustus 2018. Rancangan percobaan yang digunakan adalah Rancangan Acak Kelompok pola faktorial yang terdiri dari dua faktor dan diulang tiga kali. Faktor pertama pupuk organik cair nasa (p) dengan 5 taraf yaitu: p1 = $0 \mathrm{ml} /$ liter air, p2 = $1 \mathrm{ml} /$ liter air, p3 = $2 \mathrm{ml} /$ liter air, p4 = $3 \mathrm{ml} / \mathrm{liter}$ air, p4 = $4 \mathrm{ml} /$ liter air. Faktor kedua adalah pupuk kandang sapi (k) yang terdiri dari 4 taraf yaitu: $\mathrm{k} 1=0$ ton/ha, $\mathrm{k} 2=5$ ton/ha, $\mathrm{k} 3=10$ ton/ha, $\mathrm{k} 4=15$ ton/ha. Hasil percobaan menunjukkan: Tidak terjadi interaksi antara pupuk organik cair Nasa dan pupuk kandang sapi terhadap pengamatan tinggi tanaman, jumlah daun, bobot per tanaman, bobot per sampel, bobot per petak dan volume akar pada tanaman selada. Perlakuan pupuk organik cair pada konsentrasi p3 menunjukkan hasil terbaik terhadap tinggi tanaman, jumlah daun, dan hasil bobot per petak dan berbeda nyata dengan pengamatan bobot per tanaman dan
\end{abstract}


volume akar. Pupuk kandang sapi menunjukkan berpengaruh tidak nyata terhadap semua tinggi tanaman, jumlah daun, bobot per tanaman, bobot per sampel, bobot per petak dan volume akar pada tanaman selada.

Kata kunci: Pupuk organik cair, Pupuk kandang sapi, Tanaman selada.

\section{PENDAHULUAN}

Selada (Lactuca sativa L) termasuk dalam kelompok tanaman sayuran daun yang dikenal masyarakat. Indonesia merupakan negara agraris karena sebagian besar mata pencahariannya masyarakat berasal dari hasil pertanian. Indonesia mempunyai potensi lahan yang subur, sehingga memungkinkan berbagai jenis tanaman bisa tumbuh dengan baik. Begitu juga dalam budidaya tanaman selada. Selada merupakan salah satu jenis tanaman sayuran yang dikonsumsi daunnya. Prospek serapan pasar terhadap komoditas selada akan terus meningkat sejalan dengan peningkatan jumlah penduduk, peningkatan pendidikan masyarakat, peningkatan pendapatan dan kesejahteraan masyarakat, dan peningkatan kesukaan (preferensi) masyarakat terhadap selada (Samadi, 2014).

Beberapa kendala dalam pengembangan tanaman selada yaitu masih rendahnya potensi hasil selada karena dipengaruhi oleh faktor lingkungan dan teknis budidaya yang diterapkan oleh masyarakat. Salah satu budidaya yang belum banyak diterapkan masyarakat diantaranya ialah pemupukan yang tepat baik dosis, cara, waktu jenis dan harga. bahwa tidak tercukupinya unsur hara bagi tanaman akan menyebabkan pertumbuhan tanaman terganggu dan hasil akan menurun, demikian pula sebaliknya pertumbuhan tanaman (Haryanto et al., 2003).

Menurut Munthe, Rudite dan Istianto (2006), bahwa penggunaan pupuk organik bermanfaat untuk meningkatkan efisiensi penggunaan pupuk kimia, sehingga dosis pupuk dan dampak pencemaran lingkungan akibat penggunaan pupuk kimia dapat dikurangi. Penggunaan pupuk organik juga dapat meningkatkan aktivitas mikroorganisme tanah yang sangat bermanfaat dalam menyediakan unsur hara tanah, mengurangi pencemaran lingkungan dan mengurangi unsur hara yang bersifat racun bagi tanaman (Departemen Pertanian, 2005). Upaya ini sekaligus untuk menghemat penggunaan pupuk anorganik karena harganya cenderung mahal dan penggunaan pupuk anorganik yang berlebihan dapat menimbulkan dampak negatif terhadap lingkungan (Herman and Goenadi, 1999).

Mengingat kebutuhan selada yang semakin meningkat maka perlu meningkatkan produksinya dengan banyak faktor. Faktor yang pertama untuk meningkatkan produksi selada memanfaatkan pupuk organik cair. Pupuk organik cair adalah hasil dari pupuk cair beberapa bahan menjadi pupuk organik cair yang penggunaannya menguntungkan bagi tanaman (Abror and Prasetyo, 2018).

Menurut Hanolo (1997) bahwa dari beberapa penelitian menujukkan bahwa pemberian pupuk organik cair melalui daun memberikan pertumbuhan dan hasil tanaman yang lebih baik daripada pemberian melalui tanah. Pemberian pupuk organik cair harus memperhatikan konsentrasi atau dosis yang diaplikasikan terhadap tanaman. Semakin tinggi dosis pupuk yang diberikkan maka kandungan unsur hara yang diterima oleh tanaman akan semakin tinggi, begitu pula dengan semakin seringnya frekuensi aplikasi pupuk daun yang dilakukan pada tanaman, maka kandungan unsur hara juga semakin tinggi, namun pemberian dengan dosis yang berlebihan justru akan mengakibatkan timbulnya gejala kelayuan pada tanaman (Suwandi and Nurtika, 1987).

Oleh karena itu, pemilihan dosis yang tepat perlu diketahui oleh para petani dan hal ini dapat diperoleh melalui pengujian-pengujian di lapangan. Diduga sampai batas tertentu kombinasi antara dosis yang diberikan dengan frekuensi aplikasi pupuk daun yang dilakukan 
merupakan faktor yang dapat meningkatkan pertumbuhan dan hasil tanaman.

\section{METODE PENELITIAN}

Penelitian ini dilaksanakan di Lahan Praktek SMK PPN Tanjungsari, dengan ketinggian tempat 850 meter di atas permukaan laut, tipe curah hujan $\mathrm{C}$ dan data curah hujan 10 tahun terakhir terdapat pada Lampiran 1. Ordo tanah inseptisol dengan $\mathrm{pH}$ 5,4. Percobaan ini dilakukan pada bulan juni sampai dengan Agustus 2018.

Bahan yang digunakan adalah benih selada (Lactuca sativa L.) varietas Grand Rapid sebagai objek pengamatan, pupuk kandang sapi dari Peternakan sapi di Desa Gunung Manik, pupuk organik cair Nasa, dan air sebagai pelarut pupuk cair organik. Alat yang digunakan adalah cangkul, gembor, kokeran, karung, gelas ukur, dari akar, pacak bambu, meteran, pacak sampel, timbangan, serta alat lainnya yang mendukung dalam penelitian ini.

Rancangan percobaan yang digunakan adalah Rancangan Acak Kelompok pola faktorial yang terdiri dari dua faktor dan diulang tiga kali. Faktor pertama pupuk organik cair nasa $(\mathrm{p})$ dengan 5 taraf yaitu: $\mathrm{p} 1=0 \mathrm{ml} /$ liter air, $\mathrm{p} 2=1$ Tabel 1. Pengaruh Pupuk Organik Cair Dan Pupuk Kandang Sapi Terhadap Tinggi Tanaman.

\begin{tabular}{lcccc}
\hline \multicolumn{1}{c}{ Perlakuan } & \multicolumn{4}{c}{ Rata-rata Tinggi Tanaman $(\mathrm{cm})$} \\
\hline & 14 HST & 21 HST & $28 \mathrm{HST}$ & $32 \mathrm{HST}$ \\
\hline Pupuk Organik Cair : & & & & \\
$\mathrm{P}_{0}(0,0 \mathrm{ml} / \mathrm{L}$ air $)$ & $3,07 \mathrm{a}$ & $8,22 \mathrm{a}$ & $11,60 \mathrm{a}$ & $12,95 \mathrm{a}$ \\
$\mathrm{P}_{1}(1,0 \mathrm{ml} / \mathrm{L}$ air $)$ & $2,96 \mathrm{a}$ & $7,62 \mathrm{a}$ & $14,12 \mathrm{~b}$ & $16,48 \mathrm{bc}$ \\
$\mathrm{P}_{2}(2,0 \mathrm{ml} / \mathrm{L}$ air $)$ & $4,48 \mathrm{~b}$ & $8,56 \mathrm{a}$ & $15,37 \mathrm{c}$ & $15,94 \mathrm{bc}$ \\
$\mathrm{P}_{3}(3,0 \mathrm{ml} / \mathrm{L}$ air $)$ & $3,53 \mathrm{a}$ & $8,36 \mathrm{a}$ & $14,55 \mathrm{bc}$ & $18,20 \mathrm{c}$ \\
$\mathrm{P}_{4}(4,0 \mathrm{ml} / \mathrm{L}$ air $)$ & $3,52 \mathrm{a}$ & $8,50 \mathrm{a}$ & $12,64 \mathrm{a}$ & $15,00 \mathrm{ab}$ \\
\hline Pupuk Kandang Sapi : & & & & \\
$\mathrm{K}_{0}(0$ ton/ha $)$ & $3,50 \mathrm{a}$ & $8,22 \mathrm{a}$ & $13,67 \mathrm{a}$ & $15,30 \mathrm{a}$ \\
$\mathrm{K}_{1}($ ton/ha $)$ & $3,75 \mathrm{a}$ & $7,75 \mathrm{a}$ & $13,36 \mathrm{a}$ & $15,87 \mathrm{a}$ \\
$\mathrm{K}_{2}(10$ ton/ha $)$ & $3,47 \mathrm{a}$ & $8,46 \mathrm{a}$ & $13,81 \mathrm{a}$ & $16,07 \mathrm{a}$ \\
$\mathrm{K}_{3}(15$ ton/ha $)$ & $3,33 \mathrm{a}$ & $8,58 \mathrm{a}$ & $13,78 \mathrm{a}$ & $15,61 \mathrm{a}$ \\
\hline
\end{tabular}

Keterangan: Angka rata-rata perlakuan yang ditandai dengan huruf yang sama pada kolom yang sama

berbeda tidak nyata berdasarkan Uji Jarak Berganda Duncan pada taraf nyata $5 \%$.

8|OrchidAgro: Vol 1, No 1, Bulan Februari Tahun 2021 $\mathrm{ml} /$ liter air, p3 = $2 \mathrm{ml} /$ liter air, p4 = $3 \mathrm{ml} / \mathrm{liter}$ air, p4 = $4 \mathrm{ml} /$ liter air. Faktor kedua adalah pupuk kandang sapi $(\mathrm{k})$ yang terdiri dari 4 taraf yaitu: $\mathrm{k} 1$ $=0$ ton $/ \mathrm{ha}, \mathrm{k} 2=5$ ton/ha, $\mathrm{k} 3=10$ ton/ha, $\mathrm{k} 4=15$ ton/ha.

\section{HASIL DAN PEMBAHASAN}

1. Tinggi Tanaman

Tinggi Tanaman Data dan analisis mengenai tinggi tanaman pada umur 14, 21, 28, dan 32 HST dapat dilihat pada Lampiran 11. Hasil analisisnya tidak menunjukkan adanya interaksi antara pupuk organik cair dan pupuk kandang sapi terhadap tinggi tanaman. Pengujian dengan uji jarak berganda Duncan secara main efek 5\% dapat dilihat pada Tabel 3. Perlakuan pupuk organik cair Nasa pada umur 14 dan 21 HST tidak berpengaruh nyata terhadap tinggi tanaman. Pada umur 28 HST perlakuan pupuk organik cair Nasa p2 menunjukkan nilai terbaik, berbeda tidak nyata dengan perlakuan p3 dan berbeda nyata dengan perlakuan $\mathrm{p} 0, \mathrm{p} 1 \mathrm{dan} \mathrm{p} 4$. Pada umur 32 HST perlakuan pupuk organik cair Nasa p3 menunjukkan hasil terbaik, berbeda tidak nyata dengan perlakuan $\mathrm{p} 1$ dan $\mathrm{p} 2$ dan berbeda nyata dengan perlakuan $\mathrm{p} 0$ dan $\mathrm{p} 4$. 
2. Jumlah Daun

Hasil analisis tidak menunjukkan adanya interaksi antara pupuk organik cair dan pupuk

Tabel 2. Pengaruh Pupuk Organik Cair Dan Pupuk kandang sapi terhadap jumlah daun.

\begin{tabular}{|c|c|c|c|c|}
\hline \multirow[t]{2}{*}{ Perlakuan } & \multicolumn{4}{|c|}{ Rata-rata Jumlah Daun (Helai) } \\
\hline & 14 HST & $21 \mathrm{HST}$ & $28 \mathrm{HST}$ & $32 \mathrm{HST}$ \\
\hline \multicolumn{5}{|c|}{ Pupuk Organik Cair : } \\
\hline $\mathrm{P}_{0}(0,0 \mathrm{ml} / \mathrm{L}$ air $)$ & $1,53 \mathrm{a}$ & $2,71 \mathrm{a}$ & $12,22 \mathrm{a}$ & $14,88 \mathrm{a}$ \\
\hline $\mathrm{P}_{1}(1,0 \mathrm{ml} / \mathrm{L}$ air $)$ & $1,53 \mathrm{a}$ & $2,87 \mathrm{a}$ & $12,88 \mathrm{ab}$ & $18,72 \mathrm{a}$ \\
\hline $\mathrm{P}_{2}(2,0 \mathrm{ml} / \mathrm{L}$ air $)$ & $1,55 \mathrm{a}$ & $2,96 \mathrm{a}$ & $16,13 \mathrm{~b}$ & $21,09 \mathrm{a}$ \\
\hline $\mathrm{P}_{3}(3,0 \mathrm{ml} / \mathrm{L}$ air $)$ & $1,49 \mathrm{a}$ & $2,78 \mathrm{a}$ & $16,47 \mathrm{~b}$ & $21,16 \mathrm{a}$ \\
\hline $\mathrm{P}_{4}(4,0 \mathrm{ml} / \mathrm{L}$ air $)$ & $1,49 \mathrm{a}$ & $2,70 \mathrm{a}$ & $12,34 \mathrm{ab}$ & $18,22 \mathrm{a}$ \\
\hline \multicolumn{5}{|c|}{ Pupuk Kandang Sapi : } \\
\hline $\mathrm{K}_{0}(0$ ton/ha $)$ & $1,50 \mathrm{a}$ & $2,78 \mathrm{a}$ & $13,07 \mathrm{a}$ & $18,65 \mathrm{a}$ \\
\hline $\mathrm{K}_{1}$ ( 5 ton/ha ) & $1,52 \mathrm{a}$ & $2,71 \mathrm{a}$ & $13,35 \mathrm{a}$ & $17,98 \mathrm{a}$ \\
\hline $\mathrm{K}_{2}(10$ ton/ha $)$ & $1,51 \mathrm{a}$ & $2,81 \mathrm{a}$ & $15,32 \mathrm{a}$ & $19,43 \mathrm{a}$ \\
\hline $\mathrm{K}_{3}(15$ ton/ha $)$ & $1,54 \mathrm{a}$ & $2,91 \mathrm{a}$ & $14,28 \mathrm{a}$ & $19,20 \mathrm{a}$ \\
\hline
\end{tabular}

Keterangan: Angka rata-rata perlakuan yang ditandai dengan huruf yang sama pada kolom yang sama berbeda tidak nyata berdasarkan Uji Jarak Berganda Duncan pada taraf nyata 5\%.

Pada tabel 4 terlihat perlakuan pupuk organik cair pada umur 14 HST, 21 HST dan 32 HST berbeda tidak nyata terhadap pengamatan jumlah daun. Pada umur 28 HST menunjukkan hasil terbaik pada perlakuan p3 berbeda tidak nyata dengan perlakuan $\mathrm{p} 1, \mathrm{p} 2$, dan $\mathrm{p} 4$ dan berbeda nyata dengan perlakuan $\mathrm{p} 0$. Perlakuan pupuk kandang sapi pada umur 14, 21, 28 dan 32 HST berpengaruh tidak nyata terhadap jumlah daun. kandang sapi terhadap jumlah daun. Hasil uji efek mandiri setiap perlakuan disajikan pada Tabel 2.

Tabel 3. Pengaruh Pupuk Organik Cair Dan Pupuk Kandang Sapi Terhadap Hasil Bobot Per Tanaman, Bobot Per Petak, dan Volume akar.

\begin{tabular}{lccc}
\hline \multicolumn{1}{c}{ Perlakuan } & $\begin{array}{c}\text { Rata-rata Hasil Bobot } \\
\text { Per Tanaman }(\mathrm{g})\end{array}$ & $\begin{array}{c}\text { Rata-rata Hasil } \\
\text { Bobot Per Petak } \\
(\mathrm{kg})\end{array}$ & $\begin{array}{c}\text { Rata-rata Volume } \\
\text { Akar }(\mathrm{ml})\end{array}$ \\
\hline Pupuk Organik Cair : & $234,53 \mathrm{a}$ & $3,36 \mathrm{a}$ & $9,06 \mathrm{a}$ \\
P0 ( 0,0 ml/L air $)$ & $265,16 \mathrm{ab}$ & $3,57 \mathrm{a}$ & $10,57 \mathrm{a}$ \\
P1 $(1,0 \mathrm{ml} / \mathrm{L}$ air $)$ & $269,31 \mathrm{ab}$ & $5,25 \mathrm{~b}$ & $11,03 \mathrm{a}$ \\
P2 $(2,0 \mathrm{ml} / \mathrm{L}$ air $)$ & $320,94 \mathrm{~b}$ & $5,57 \mathrm{c}$ & $10,40 \mathrm{a}$ \\
P3 $(3,0 \mathrm{ml} / \mathrm{L}$ air $)$ & $208,44 \mathrm{a}$ & $4,47 \mathrm{~b}$ & $9,92 \mathrm{a}$ \\
P4 (4,0 ml/L air) & &
\end{tabular}




\begin{tabular}{|c|c|c|c|}
\hline Perlakuan & $\begin{array}{l}\text { Rata-rata Hasil Bobot } \\
\text { Per Tanaman }(\mathrm{g})\end{array}$ & $\begin{array}{c}\text { Rata-rata Hasil } \\
\text { Bobot Per Petak } \\
(\mathrm{kg})\end{array}$ & $\begin{array}{l}\text { Rata-rata Volume } \\
\text { Akar (ml) }\end{array}$ \\
\hline \multicolumn{4}{|c|}{ Pupuk Kandang Sapi : } \\
\hline $\mathrm{K}_{0}(0$ ton/ha $)$ & $257,28 \mathrm{a}$ & $4,14 \mathrm{a}$ & $10,41 \mathrm{a}$ \\
\hline $\mathrm{K}_{1}(5$ ton/ha $)$ & $247,55 \mathrm{a}$ & $4,29 \mathrm{a}$ & $9,91 \mathrm{a}$ \\
\hline $\mathrm{K}_{2}(10$ ton/ha $)$ & 286,38 a & $4,47 \mathrm{a}$ & $9,54 \mathrm{a}$ \\
\hline $\mathrm{K}_{3}$ ( 15 ton/ha $)$ & $247,50 \mathrm{a}$ & $4,66 \mathrm{a}$ & $10,93 \mathrm{a}$ \\
\hline
\end{tabular}

Keterangan: Angka rata-rata perlakuan yang ditandai dengan huruf yang sama pada kolom yang sama berbeda tidak nyata berdasarkan Uji Jarak Berganda Duncan pada taraf nyata 5\%.

Pada Tabel 3. terlihat perlakuan pupuk organik cair pada umurperlakuan p3 menujukkan hasil terbaik dan berbeda tidak nyata terhadap perlakuan $\mathrm{p} 1$ dan $\mathrm{p} 2$ serta berbeda nyata terhadap perlakuan p0 dan p4. Pada perlakuan pupuk kandang sapi menjukkan tidak berbeda nyata terhadap pengamatan bobot per tanaman.

\section{PEMBAHASAN}

Hasil percobaan menunjukkan tidak terjadi interaksi antara pupuk organik cair dan pupuk kandang sapi terhadap pertumbuhan dan hasil tanaman selada varietas Grand Rapids. Hasil analisis mandiri ternyata pemberian perlakuan pupuk organik cair terhadap pengamatan tinggi tanaman umur 21 HST, 14 HST dan 21 HST menujukkan berbeda nyata pada pengamatan jumlah daun dan volume akar. Akan tetapi menunjukkan berbeda tidak nyata terhadap pengamatan tinggi tanaman umur 14, 28 dan 32 HST, jumlah daun pada umur 28 HST dan 32 HST, bobot per tanaman dan bobot per petak.

Tabel 3. Memperlihatkan perlakuan konsentrasi POC ternyata pada umur 21 menunjukkan berbeda tidak nyata, sedangkan pada umur 14, dan 28 HST perlakuan p2 (2,0 ml per liter air) menunjukkan pertumbuhan tinggi tanaman yang lebih tinggi. dan pada umur 32 HST perlakuam p3 $(3,0 \mathrm{ml}$ per liter air $)$ menunjukkan pertumbuhan lebih tinggi dibanding perlakuan lainnya. Hal ini disebabkan pemberian POC dengan konsentrasi 2,0 ml per liter air dan 3,0 ml per liter air merupakan konsentrasi yang cukup bagi tanaman selada sehingga dapat meningkatkan aktivitas pertumbuhan tanaman. Pemberian POC yang disemprotkan melalaui daun dapat menambah ketersediaan unsur hara makro dan mikro yang dibutuhkan oleh tanaman selada, terutama unsur hara yang ketersediaannya di dalam tanah rendah seperti N, P, K,Ca dan Na. POC mengandung unsur hara makro (N, P, K, Ca, Mg dan $\mathrm{S}$ ) dan mikro (Fe dan $\mathrm{S}$ ) yang dilengkapi dengan asam humat, asam fulvat, zat pengatur tumbuh (IAA, auksin, giberelin, dan sitokinin) serta asam-asam amino dan lemak nabati menyebabkan ketersediaan unsur hara tersebut meningkat (PT. Natural Nusantara Jogjakarta, 2004).

Geswono (1983) mengemukakan bahwa ketersediaan $\mathrm{N}$ bagi tanaman penting dalam proses fotosintesis. Fosfor pada tanaman memegang peranan penting dalam kebanyakan reaksi enzim, seperti fosforilasi dalam proses fotosintesis dan perubahan karbohidrat pada tanaman. Kalium pada tanaman adalah untuk mempertahankan tekanan turgor tanaman yang sangat diperlukan dalam proses absorpsi $\mathrm{CO} 2$, sehingga proses fotosintesis dan metabolisme lainnya dapat berlangsung baik. Sedangkan ketersediaan $\mathrm{Ca}$ yang memadai juga sangat penting sebagai penyusun dinding sel dan berperan dalam mengatur permeabilitas dinding sel (daya tembus cairan). $\mathrm{Mg}$ berperan dalam klorofil dan sistem enzim. S berperan dalam pembentukkan protein. Dengan demikian, ketersediaan unsur $\mathrm{N}, \mathrm{P}, \mathrm{K}, \mathrm{Ca}, \mathrm{Mg}$ dan $\mathrm{S}$ bagi 
tanaman dapat meningkatkan aktivitas fotosintesis tanaman yang pada akhirnya akan memacu pertumbuhan vegetatif tanaman. Selain itu juga peningkatan tinggi tanaman pada umur 14, 28 dan 32 HST adanya peranan zat tumbuh (Auksin, Giberelin, dan Sitokinin) dari POC yang dapat merangsang pertumbuhan tanaman.

Pada pengamatan jumlah daun (Tabel 4) pada umur $28 \mathrm{HST}$ pada perlakuan p3 (3,0 ml per liter air) menunjukkan hasil terbaik dan berbeda nyata dengan perlakuan p0 (kontrol) serta berbeda Tidak nyata terhadap perlakuan $\mathrm{p} 1, \mathrm{p} 2$, dan p4. Peningkatan jumlah daun pada konsentrasi 1,0- 4,0 $\mathrm{ml}$ per liter air disebabkan pemberian POC dapat meningkatkan ketersediaan $\mathrm{N}$ bagi tanaman, yang ketersediaannya rendah di dalam tanah. Menurut Goeswono (1983) bahwa unsur yang berpengaruh terhadap pertumbuhan dan perkembangan daun adalah unsur N. Konsentrasi N yang tinggi pada umumnya menghasilkan jumlah daun yang lebih banyak dengan ukuran yang lebih luas. Mas'ud (1993) menjelaskan bahwa pemberian unsur hara pada tanaman terbukti mampu memberikan pertumbuhan tanaman jika konsentrasi atau dosis yang diberikan berada pada kisaran kebutuhan tanaman.

Tabel 5. Memperlihatkan rata-rata hasil bobot per tanaman pemberian pupuk organik cair Pada perlakuan pupuk organik cair perlakuan p3 menujukkan hasil terbaik dan berbeda tidak nyata terhadap perlakuan $\mathrm{p} 1$ dan $\mathrm{p} 2$ serta berbeda nyata terhadap perlakuan $\mathrm{p} 0$ dan $\mathrm{p} 4$. Hal ini diduga bahwa pemberian pupuk organik cair direspon baik oleh tanaman karena unsur hara menjadi cukup tersedia dalam tanah. Prmberian pupuk organik cair tersebut dapat menciptakan suatu kadar zat hara yang lebih tinggi dalam larutan tanah sehingga selanjutnya diabsorpsi oleh tanaman dan dimanfaatkan untuk proses perkembangan tanaman. Hal ini sesuai dengan pendapat Sifuddin (1989) serta Sutedjo dan Kartasapoertra (1990) yang menyatan bahwa salah satu faktor yang dapat mempengaruhi tingkat produksi suatu tanaman adalah terpenuhinya unsur hara yang diserap oleh tanaman sepanjang masa hidupnya.

$$
\text { Pada hasil penelitian buncis }
$$

menunjukkan bahwa pertumbuhan dan perkembangan tanaman buncis akan baik jumlah unsur hara yang diberikan turut diperhatikan. Hal ini disebabkan karena pemberian pupuk dengan dosis yang tidak sesuai akan berpengaruh terhadap hasil tanaman. Menurut Gardner et al, (1991), pemupukan di zona defisien akan meningkatkan bobot kering tanaman, sedangkan pemupukan di zona berlebihan akan mengakibatkan peningkatankandungan unsur hara tertentu di dalam jaringan tanaman. Apabila hal ini terjadi, maka efisiensi pemupukan tercapai. Dengan demikian, diperlukan adanya pengujian-pengujian untuk mendapatkan suatu rekomendasi pemupukan yang sesuai tentang dosis dan frekuensi pemberian pupuk yang dianjurkan, khususnya pupuk organik cair.

Hasil pengamatan pada hasil bobot per petak (Tabel 5) Pada perlakuan pupuk organik cair menujukkan hasil terbaik pada perlakuan p3, berbeda nyata pada perlakuan p0, p1, p2 dan p4. Ketersediaan unsur hara akibat pemberian POC berpengaruh terhadap proses fotosintesis sehingga fotosintat yang dihasilkan akan lebih banyak. Hasil fotosintesis diakumulasikan ke organ-organ tanaman lainnya seperti bobot per petak. Dengan demikian pemberian POC mampu memberikan pengaruh yang baik terhadap pertumbuhan dan hasil selada.

Pada pengamatan volume akar (Tabel 5) menujukkan bahwa tidak berbeda nyata. Hal ini diduga sebagaina besar fotosintat yang dihasilkan tanaman selada varietas Grand Rapids digunakan untuk perkembangan bagian atas tanaman dibanding perkembangan akar tanaman dan besarnya nisbah tersebut tidak dipengaruhi oleh perbedaan perlakuan pupuk organik cair. Hasil analisis mandiri ternyata pemberian perlakuan pupuk kandang sapi pada dosis yang berbeda terhadap pengamatan tinggi tanaman, jumlah 
daun, bobot per tanaman, bobot per petak dan volume akar menunjukkan berbeda tidak nyata pada semua pengamatan.

Hal ini diduga disebabkan oleh beberapa faktor, yakni pupuk kandang sapi merupakan pupuk yang tergolong mempunyai proses dekomposisi yang lambat, sehingga tanaman selada yang berumur pendek sulit mendapatkan unsur hara yang terdapat pada pupuk kandang sapi tersebut. hal ini sesuai dengan pernyataan Haryanto et al, (2003) bahwa pupuk kandang sapi tergolong pupuk dingin, proses perubaannya berlangsung lambat dan kurang sekali terbentuk panas. Lambatnya proses dekomposisi ini disebabkan oleh sifat fisik padatannya banyak mengandung air dan lendir. Karena dengan adanya lendir bila terkena udara pupuk ini menjadi bergkerak dan bagian luarnya mengering sehingga proses oksidasi berjalan lambat karena udara dan air sulit masuk kedalamnya.

Sehingga unsur hara di dalam tanah yang digunakan sebagai media tanam percobaan dapat dikatan belum menunjang untuk pertumbuhan dan perkembangan tanaman diantaranya $\mathrm{C}$ Organik, N-Total, C/N, P2O5, K-dd, Na-, Mg-dd, kejenuhan Basa, Al-dd, H-dd, dan kejenuhan $\mathrm{Al}$ dikategorikan rendah. unsur hara makro dan mikro yang ada di dalam tanah merupakan salah satu komponen penunjang pertumbuhan dan perkembangan tanaman. Faktor lain yaitu pengairan, karena pada saat percobaan dilakukan pada musim kering sehingga kelembaban tanah menjadi kurang.

\section{KESIMPULAN DAN SARAN}

\section{Kesimpulan}

Berdasarkan hasil percobaan tersebut, maka dapat disimpulkan Tidak terjadi interaksi antara pupuk organik cair dan pupuk kandang sapi terhadap pengamatan tinggi tanaman, jumlah daun, bobot per tanaman, bobot per sampel, bobot per petak dan volume akar pada tanaman selada. Dan Perlakuan pupuk organik cair pada konsentrasi p3 (3,0 ml per liter air) menunjukkan hasil terbaik terhadap tinggi tanaman, jumlah daun, hasil bobot per tanaman, dan hasil bobot per petak dan berbeda nyata pada pengamatan volume akar. Dan pada perlakuan Pupuk kandang sapi menunjukkan berpengaruh tidak nyata terhadap semua tinggi tanaman, jumlah daun, bobot per tanaman, bobot per petak dan volume akar pada tanaman selada.

\section{Saran}

1. Untuk memperoleh pertumbuhan dan hasil tanaman selada varietas Grand Rapids sebaiknya aplikasi pupuk organik cair digunakan konsentrasi 3,0 $\mathrm{ml}$ per liter air.

2. Disarankan perlu dilakukan percobaan lebih lanjut terhadap lahan percobaan yang sudah dipupuk dengan pupuk kadang sapi sebaiknya ditanami oleh tanaman yang berumur panjang karena proses dekomposisi pupuk kandang sapi berjalan lambat sehingga unsur hara yang terdapat pada pupuk kandang sapi bisa terserap oleh tanaman.

3. Untuk memperoleh informasi lebih lanjut tentang pengaruh konsentrasi pupuk organik cair dan takaran pupuk kandang sapi yang berbeda perlu dicoba pada berbagai varietas dan lokasi yang berbeda sehingga informasi mengenai pemberian pupuk organik cair dan takaran pupuk kandang sapi dapat diketahui lebih lengkap.

\section{DAFTAR PUSTAKA}

Abror, M., and T. Prasetyo. 2018. Pengaruh Pupuk Cair dan Pupuk Kandang Sapi terhadap Pertumbuhan dan Produksi Tanaman Selada (Lactuca sativa L.). AGROTECHBIZ 05(01): 1-6.

Gardner, F.P., R.B. Pearce, and R.L. Mitchell. 1991. Physiology of Crop Plants (Fisiologi Tanaman Budidaya, Alih Bahasa Oleh Herawati Susilo). Univ. Indones. Press.

Goeswono, S. 1983. Sifat dan Ciri Tanah. 
Halono. 1997. Tanggapan Tanaman Selada dan Sawi terhadap Dosis dan Cara Pemberian Pupuk Cair Stimulant. J. Agrotropika 1(1): 25-29.

Haryanto, E., T. Suhartini, E. Rahayu, and H. Sunarjono. 2003. Sawi dan Selada. Penebar Swadaya.

Herman, and Goenadi. 1999. Manfaat dan Prospek Industri Hayati di Indonesia. J. Penelit. dan Penggembangan Pertan. 18(3): 91-97.

Mas'ud, P. 1993. Telaah Kesuburan Tanah. Angkasa Bandung: 320.

Munthe, H., T. Rudite, and Instianto. 2006. Penggunaan Pupuk Organik Pada Tanaman Karet Menghasilkan. Balai Penelit. Sungai Putih Penelit. Karet Indones.: 36-37.

Pertanian, D. 2005. Warta Penelitian dan Pengembangan Pertanian. : 6 .

PT. Natural Nusantara Jogjakarta. 2004. Panduan Produk PT. Natural Nusantara. PT. Nat. Nusant.

Saifuddin, S. 1989. Kesuburan dan Pemupukan Tanah Pertanian. Pustaka Buana.

Samadi, B. 2014. Rahasia Budidaya Selada Secara Organik dan Anorganik. Pustaka Mina.

Sutedjo, M.M., and Katasapoetra. 1990. Pupuk dan Cara Pemupukan. Rineka Cipta.

Suwandi, and Nurtika. 1987. Pengaruh Pupuk Biokimia "Sari Humus" pada Tanaman Kubis. Bul. Penelit. Hortik. 15(20): 213218. 